\title{
Chromosomal mapping of rRNA genes, core histone genes and telomeric sequences in Brachidontes puniceus and Brachidontes rodriguezi (Bivalvia, Mytilidae)
}

Concepción Pérez-García, Jorge Guerra-Varela, Paloma Morán, Juan J Pasantes*

\begin{abstract}
Background: Chromosome rearrangements are an important part of the speciation process in many taxa. The study of chromosome evolution in bivalves is hampered by the absence of clear chromosomal banding patterns and the similarity in both chromosome size and morphology. For this reason, obtaining good chromosome markers is essential for reliable karyotypic comparisons. To begin this task, the chromosomes of the mussels Brachidontes puniceus and B. rodriguezi were studied by means of fluorochrome staining and fluorescent in situ hybridization (FISH).

Results: Brachidontes puniceus and B. rodriguezi both have $2 n=32$ chromosomes but differing karyotype composition. Vertebrate-type telomeric sequences appear at both ends of every single chromosome. B. puniceus presents a single terminal major rRNA gene cluster on a chromosome pair while $B$. rodriguezi shows two. Both mussels present two $5 \mathrm{~S}$ rDNA and two core histone gene clusters intercalary located on the long arms of two chromosome pairs. Double and triple-FISH experiments demonstrated that one of the 5S rDNA and one of the major rDNA clusters appear on the same chromosome pair in B. rodriguezi but not in B. puniceus. On the other hand, the second 5S rDNA cluster is located in one of the chromosome pairs also bearing one of the core histone gene clusters in the two mussel species.

Conclusion: Knowledge of the chromosomal distribution of these sequences in the two species of Brachidontes is a first step in the understanding of the role of chromosome changes on bivalve evolution.
\end{abstract}

\section{Background}

Over recent years, an increasing number of molecular studies have focused on the elucidation of the phylogenetic relationships among species of bivalves in order to further reveal their evolutionary history [1]. Nevertheless, cytogenetic comparisons between species remain quite rare mainly due to difficulties in obtaining good chromosome banding patterns [2]. This fact, together with the small differences in chromosome size and morphology in many species of bivalves, makes the unequivocal identification of each chromosome pair very difficult and therefore, complicates cytogenetic comparisons.

\footnotetext{
* Correspondence: pasantes@uvigo.es
}

Dpto. Bioquímica, Xenética e Inmunoloxía. Universidade de Vigo. Vigo, Spain
Fluorescent in situ hybridization (FISH) allows combining cytogenetic and molecular techniques, improving our understanding of genome organization. The chromosomal mapping of different types of DNA sequences in bivalves has greatly increased over the last years [2-4]. Although the information gained so far is of great importance in the analysis of chromosome evolution in bivalves, the data obtained are still scarce and focused on a limited number of DNA sequences, mainly in species with commercial interest.

Most FISH reports in bivalves have been concentrated on the chromosomal localization of major rRNA genes rather than on other gene families such as $5 \mathrm{~S}$ rDNAs and histone genes [2,5]. Major rDNA has been located in about 50 species of bivalves [2,5], including seven species of the family Mytilidae [5-11]. 5S rDNA has 
been located in a small number of species belonging to the families Cardiidae [12], Mytilidae [5,11], Ostreidae $[13,14]$ and Pectinidae [15-20]. The organization of the histone genes has been characterized in two species of mussels [21-24], one scallop [25] and three species of venerid clams [26] but their chromosomal locations are only known in two species of mussels $[5,22,24]$ and four species of Pectinidae [27]. Telomeric sequences have been characterized and located in a few species of bivalves, including two species of Mytilidae [5,6,28].

Brachidontes (senegalensis) puniceus (Gmelin 1791) is a small mussel species native to the African Atlantic coast, from Mauritania to Angola. B. rodriguezi (d'Orgbigny 1846) is a medium-sized mussel distributed from Río Grande do Sul (Brazil) to the northern part of Patagonia (Argentina) on the Atlantic coast of South America. Karyological data on the genus Brachidontes is limited to the knowledge of the karyotypes and the chromosomal location of the major rDNA in B. rodriguezi [8] and B. pharaonis [10]. In order to expand the cytogenetic information on the family Mytilidae, we analyzed the chromosomes of B. puniceus and B. rodriguezi by means of 4',6-diamidino-2-phenylindole (DAPI)/propidium iodide (PI) and chromomycin A3 (CMA)/DAPI fluorescence staining and fluorescent in situ hybridization (FISH) with 28S rDNA, 5S rDNA, core histone genes and telomeric probes.

\section{Methods}

\section{Animals}

Samples of Brachidontes puniceus were collected at São Vicente (Cape Verde) and São Tomé (São Tomé and Principe). B. rodriguezi specimens were collected at Mar del Plata (Argentina). Mussels were maintained in the laboratory in tanks of $5 \mathrm{~L}$ of aerated, filtered seawater at $18 \pm 1^{\circ} \mathrm{C}$ and fed on a mixture of microalgae cells (Isochrysis galbana and Tetraselmis suecica) for at least 15 days in order to promote both somatic growth and gonadic maturation.

\section{Chromosome preparation and fluorochrome staining}

Chromosome preparations were obtained following the technique described previously [6]. Juvenile specimens were housed in $0.5 \mathrm{~L}$ beakers and exposed to colchicine $(0.005 \%)$ for $12 \mathrm{~h}$. Gill and mantle tissues were excised and immersed in $50 \%$ and $25 \%$ seawater for $90 \mathrm{~min}$ and fixed with ethanol/acetic acid for $1 \mathrm{~h}$. Chromosome spreads were obtained by dissociating small pieces of tissue in $60 \%$ acetic acid, pipetting suspension drops onto slides heated to $55^{\circ} \mathrm{C}$ and air-drying.

Some chromosome preparations were stained for $2 \mathrm{~h}$ with CMA $\left(0.25 \mathrm{mg} \mathrm{mL}^{-1}\right)$ and counterstained with DAPI $\left(0.14 \mu \mathrm{g} \mathrm{mL}^{-1}\right)$ for $8 \mathrm{~min}$. Once washed with distilled water, slides were air-dried and mounted with antifade (Vectashield, Vector). After visualization and photography, preparations were washed and re-stained with a combination of DAPI $\left(0.14 \mu \mathrm{g} \mathrm{mL}^{-1}\right)$ and PI $(0.07$ $\left.\mu \mathrm{g} \mathrm{mL}^{-1}\right)$. The slides were then washed in distilled water, air-dried, mounted in antifade and photographed again.

Chromosome counts and karyotype analysis were performed in 10 specimens ( 5 males, 5 females) of each species. In order to determine the karyotype of Brachidontes puniceus, ten good metaphase plates were used to construct karyotypes. Chromosome and arm lengths were carefully measured and relative lengths and centromeric indices were calculated. Chromosome nomenclature follows Levan et al. [29].

\section{DNA extraction, PCR amplification and probe labeling}

Total DNA was extracted following the method of Estoup et al. [30] with minor modifications. About $3 \mathrm{mg}$ of adductor muscle tissue was homogenized in $0.4 \mathrm{~mL}$ of a pre-warmed $\left(60^{\circ} \mathrm{C}\right) 10 \%$ Chelex 100 (BioRad) solution. After adding pronase $\left(1.4 \mathrm{mg} \mathrm{mL}^{-1}\right)$ and incubating for $1 \mathrm{~h}$ at $60^{\circ} \mathrm{C}$ in agitation, the extracted DNA was stored at $4^{\circ} \mathrm{C}$.

FISH probes were obtained by PCR. Amplifications were performed in $20 \mu \mathrm{l}$ of a solution containing $50 \mathrm{ng}$ DNA, $1 \times$ PCR buffer, $0.5 \mathrm{mM}$ each dNTP, $2.5 \mathrm{mM}$ $\mathrm{MgCl}_{2}, 1 \mu \mathrm{M}$ each primer and $1 \mathrm{U}$ BIOTAQ DNA polymerase (Bioline). The combinations of primers used in the amplification appear in Table 1. Universal primers (LR1OR, LR12) were used to amplify a fragment of the $28 \mathrm{~S}$ rRNA gene of the major rDNA repeat [31]. For the $5 \mathrm{~S}$ rDNA amplification, primers were designed from the sequence of the 5S rRNA of Mytilus edulis [32]. The amplifications of the $\mathrm{H} 2 \mathrm{~B} / \mathrm{H} 2 \mathrm{~A}$ and the $\mathrm{H} 3$ histone genes were performed using primers designed from the sequences of the histone genes of Mytilus edulis [23] and those described by Giribet and Distel [1], respectively. After 5 min denaturation at $95^{\circ} \mathrm{C}, 30$ cycles of amplification were performed using the conditions that are shown in Table 1. A final extension step of $7 \mathrm{~min}$ at $72^{\circ} \mathrm{C}$ was applied. All reactions were performed in a GeneAmp PCR system 9700 (Applied Biosystem) and PCR products were examined by electrophoresis on a $2 \%$ agarose gel. Single products were obtained after amplification using each set of primers. 28S rDNA was labeled with biotin 16-UTP and/or digoxigenin-UTP (10× DIG Labeling Mix, Roche) by nick translation. 5S rDNA and histone genes were directly labeled by PCR either with biotin-16-UTP or digoxigenin-UTP. The labeled PCR products were precipitated before FISH.

\section{Fluorescent in situ hybridization (FISH)}

Single and double FISH experiments were performed following the methods published previously [33] with 
Table 1 Primers and parameters used in the PCR

\begin{tabular}{|c|c|c|c|c|}
\hline Gene & Sequences of the primers & Denaturation & Annealing & Elongation \\
\hline 285 & $\begin{array}{l}\text { LR10R: 5'GACCCTGTTGAGCTTGA3' } \\
\text { LR12: 5'GACTTAGAGGCGTTCAG3' }\end{array}$ & $95^{\circ} \mathrm{C}, 20 \mathrm{~s}$ & $48^{\circ} \mathrm{C}, 20 \mathrm{~s}$ & $72^{\circ} \mathrm{C}, 30 \mathrm{~s}$ \\
\hline $5 S$ & $\begin{array}{l}\text { F: 5'CAACGTGATATGGTCGTAGAC3' } \\
\text { R: 5'AACACCGGTTCTCGTCCGATC3' }\end{array}$ & $95^{\circ} \mathrm{C}, 30 \mathrm{~s}$ & $44^{\circ} \mathrm{C}, 30 \mathrm{~s}$ & $72^{\circ} \mathrm{C}, 30 \mathrm{~s}$ \\
\hline$h 2 b a$ & $\begin{array}{l}\text { F: 5TCCCGAGATGTGATGGTAGA3' } \\
\text { R: 5'AGTACAGCCTGGATGTITGGTAA3' }\end{array}$ & $95^{\circ} \mathrm{C}, 30 \mathrm{~s}$ & $45^{\circ} \mathrm{C}, 30 \mathrm{~s}$ & $72^{\circ} \mathrm{C}, 40 \mathrm{~s}$ \\
\hline h3 & $\begin{array}{l}\text { F: 5'ATGGCTCGTACCAAGCAGACVGC3' } \\
\text { R: 5'ATATCCTTRGGCATRATRGTGAC3' }\end{array}$ & $95^{\circ} \mathrm{C}, 15 \mathrm{~s}$ & $48^{\circ} \mathrm{C}, 15 \mathrm{~s}$ & $72^{\circ} \mathrm{C}, 15 \mathrm{~s}$ \\
\hline
\end{tabular}

minor modifications. Preparations were denatured at $69^{\circ}$ $\mathrm{C}$ for $2 \mathrm{~min}$ and hybridized overnight at $37^{\circ} \mathrm{C}$. Signal detection was carried out with fluorescein avidin and biotinylated anti-avidin for the biotinylated probes and with mouse antidigoxigenin, goat anti-mouse rhodamine and rabbit anti-goat rhodamine for the digoxigeninlabeled probes. Slides were counterstained with DAPI and mounted in antifade.

In order to map three probes on the same metaphase plates, two consecutive FISH were performed. In the first one, a histone gene probe labeled with biotin and a $5 \mathrm{~S}$ rDNA probe labeled with digoxigenin were employed. After visualization and photography, the preparations were re-hybridized using a $28 \mathrm{~S}$ rDNA probe simultaneously labeled by nick translation with both biotin and digoxigenin and the same metaphase plates were visualized and photographed again. In addition, we also performed FISH with a telomeric (CCCTAA) 3 peptide nucleic acid (PNA) probe (Applied Biosystems) following the protocol indicated by the supplier.

Slide visualization and photography were performed with a Nikon Eclipse-800 microscope equipped with an epifluorescence system. Separated images for each fluorochrome were obtained with a Sensys CCD camera (Photometrics) connected to the microscope. Camera control and digital image acquisition employed a Power Macintosh computer. Pseudocoloring and merging of the images was performed with Adobe Photoshop.

\section{Results}

Coinciding with previously reported data [8], Brachidontes rodriguezi presents a diploid chromosome number of $2 \mathrm{n}=32$ (Figure $1 \mathrm{i}-\mathrm{p}$ ) and its karyotype is composed of 2 metacentric, 12 subtelocentric and 2 telo/subtelocentric chromosome pairs (Figure 2j). $B$. puniceus also shows a diploid complement of $2 \mathrm{n}=32$ chromosomes (Figure 1a-h). The karyotype is composed of 1 metacentric, 3 submetacentric, 4 submeta/subtelocentric, 4 subtelocentric and 4 telocentric chromosome pairs (Figure 2i). A summary of the results obtained after measuring the DAPI-stained chromosomes of 10 of the best complete metaphase plates is given in Table 2 .
No differences were observed between the São Vicente and São Tomé populations.

Telomeric sequences were detected using a vertebrate telomeric (CCCTAA) 3 PNA probe. Single distinct terminal signals appear at the ends of both sister chromatids of every mitotic chromosome in the two species (Figure 1d, h, l, p). No additional interstitial telomeric sequences were observed. Although the sizes of the telomeric signals do not show a high variability, consistently bigger signals appear at terminal regions of the long arm of one of the members of one chromosome pair in Brachidontes puniceus (Figure 1d) and of the short arms of two chromosome pairs in B. rodriguezi (Figure 11). One of the $B$. puniceus mussels presents an additional bigger telomeric signal (Figure $1 \mathrm{~h}$ ) and one of the B. rodriguezi specimens shows only three bigger telomeric signals (Figure 1p).

DAPI/PI staining of mitotic metaphase plates reveals the presence of a DAPI negative (DAPI-) terminal region on the long arm of the subtelocentric chromosome pair \# 15 in Brachidontes puniceus (Figure 1a, e). One of the mussels shows an additional DAPI- band on the short arm of the chromosome pair also bearing the standard band (Figure 1e). CMA staining of the same metaphase plates (Figure $1 \mathrm{~b}, \mathrm{f}$ ) shows that these regions are CMA bright $(\mathrm{CMA}+)$. B. rodriguezi presents DAPI-/CMA+ regions on the short arms of the two telo/subtelocentric chromosome pairs, \# 4 and \# 6 (Figure 1i, j, m, n), but one of the individuals analyzed shows only three DAPI-/ $\mathrm{CMA}+$ positive regions in every single cell (Figure $1 \mathrm{~m}, \mathrm{n}$ ).

FISH signals for the major ribosomal genes were analyzed in 130 complete metaphase plates in five Brachidontes puniceus mussels and in 150 metaphases in five specimens of B. rodriguezi. B. puniceus presents two major rDNA signals on a terminal region of the long arm of the subtelocentric chromosome pair \# 15 (Figure 1c). These signals coincide with the DAPI-/CMA+ regions (Figure 1a, b). The mussel showing an additional DAPI-/CMA + region (Figure 1e, $\mathrm{f}$ ) also presents a third $28 \mathrm{~S}$ rDNA signal at the same position (Figure 1g). Most $B$. rodriguezi mussels present four major ribosomal signals, coincident with the DAPI-/CMA+ regions, on the 

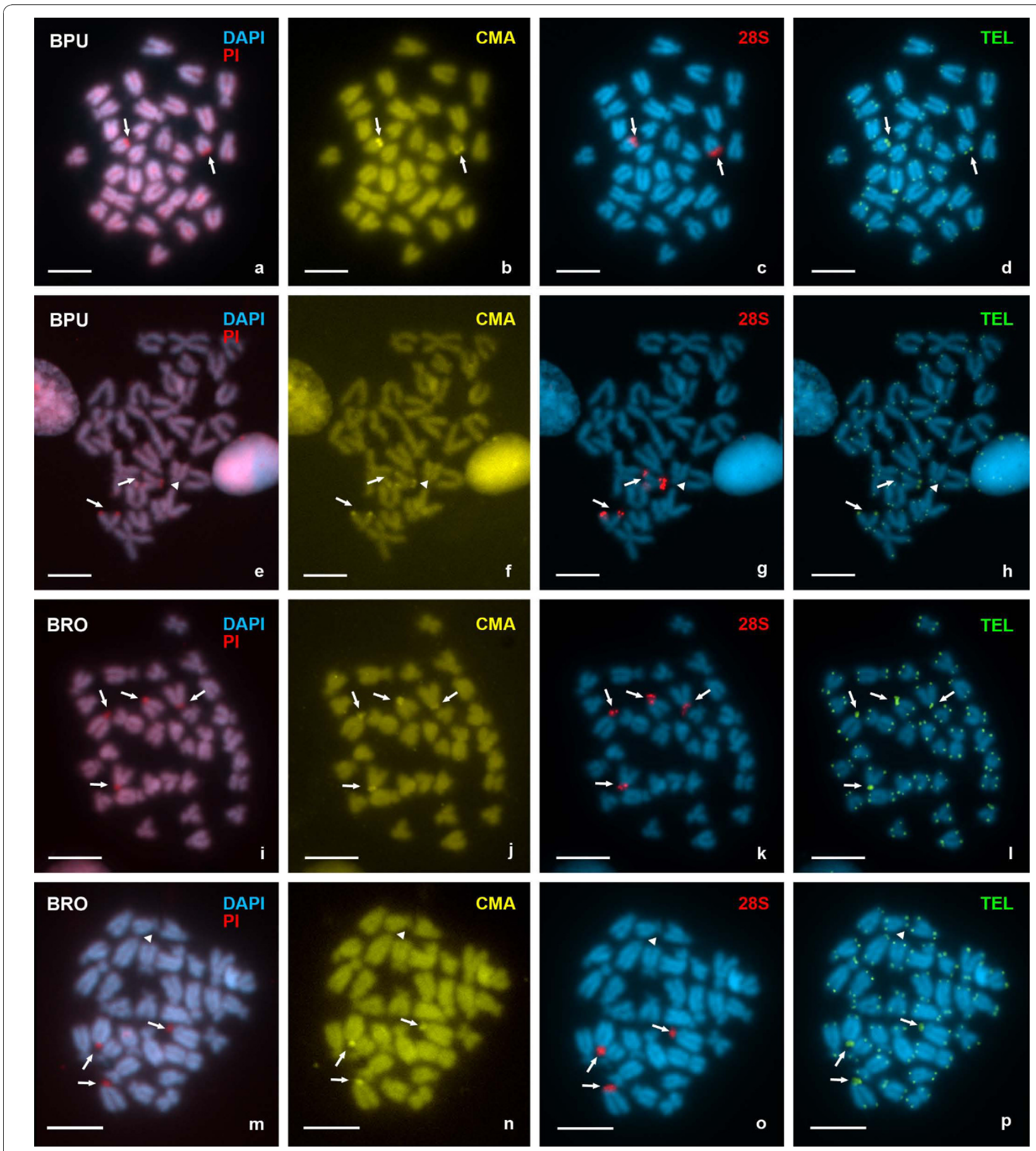

Figure 1 Sequential DAPI/PI and CMA staining followed by FISH using $28 \mathrm{~S}$ rDNA (28S) and telomeric (TEL) probes on Brachidontes puniceus (BPU) and Brachidontes rodriguezi (BRO) chromosomes. Sequential staining of the same metaphase plates with DAPI/PI (a, e) and CMA (b, $\mathbf{f})$ shows the presence of two GC-rich (DAPI dull/CMA bright) regions located at the ends of the long arms on one chromosome pair in B. puniceus (arrows in $\mathbf{a}, \mathbf{b}, \mathbf{e}, \mathbf{f}$ ). One of the B. puniceus specimens shows an additional GC-rich region on the short arm of one of the members of the chromosome pair bearing the standard band (arrowhead in $\mathbf{e}, \mathbf{f}$ ). In B. rodriguezi four GC-rich regions appear on the short arms of two chromosome pairs (arrows in $\mathbf{i}, \mathbf{j}$ ) but one of the mussels shows only three of these bands (arrows in $\mathbf{m}, \mathbf{n}$ ) lacking the fourth (arrowhead in $\mathbf{m}$, n). FISH using a $28 \mathrm{~S}$ rDNA probe (digoxigenin, rhodamine, red) gives signals at the CMA+ positions in both B. puniceus (arrows in $\mathbf{c}$, $\mathbf{g}$, arrowhead in $\mathbf{g}$ ) and B. rodriguezi (arrows in $\mathbf{k}, \mathbf{o}$ ). Note the absence of the fourth major rDNA signal in $\mathbf{o}$ (arrowhead). FISH using a PNAtelomeric probe (fluorescein, green) gives signals at both ends of every sister chromatid. Telomeric signals situated on the GC-rich NORs are consistently bigger than the rest of the telomeric signals and their sizes are similar to the sizes of the $28 \mathrm{~S}$ signals (arrows in $\mathbf{d}, \mathbf{h}, \mathbf{l}, \mathbf{p}$ ). Scale bars, $5 \mu \mathrm{m}$. 

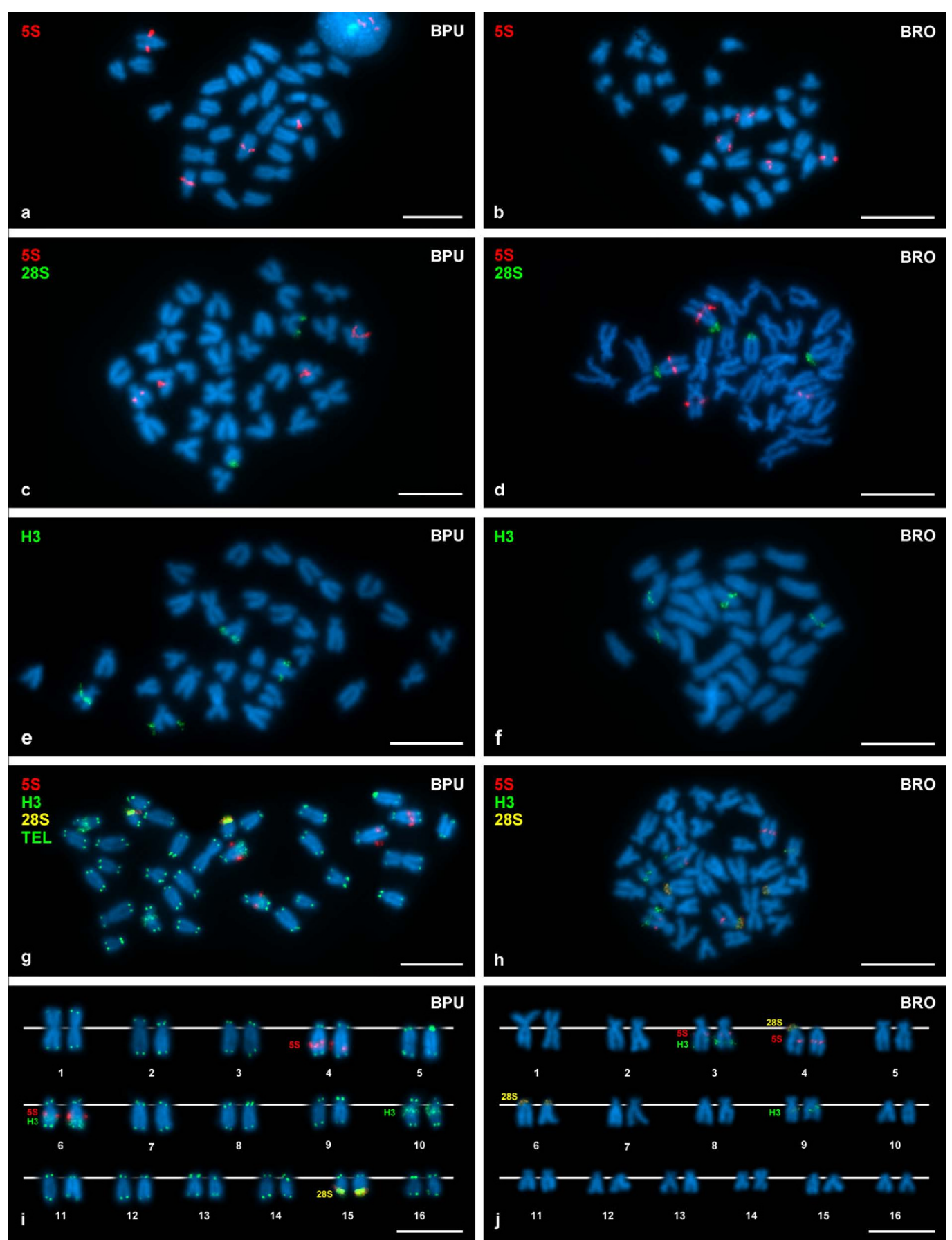

Figure 2 Chromosomal location of 5 S rDNA, major rDNA and core histone genes on Brachidontes puniceus and Brachidontes rodriguezi. FISH using a $5 \mathrm{~S}$ rDNA probe (digoxigenin, rhodamine, red) reveals the presence of two clusters of $5 S$ rDNA on two chromosome pairs in both B. puniceus (BPU, a) and B. rodriguezi (BRO, b). Double-FISH experiments using a 5S rDNA probe (digoxigenin, rhodamine, red) and a 285 rDNA probe (biotin, fluorescein, green) show that major and minor gene clusters in B. puniceus (c) are to be found on different chromosome pairs but that in B. rodriguezi (d) one of the chromosome pairs bearing a 55 rDNA signal also bears one of the major rDNA signals. FISH using a histone $\mathrm{H} 3$ gene probe (biotin, fluorescein, green) shows two clusters of core histone genes on the long arms of two chromosome pairs in both B. puniceus (e) and B. rodriguezi (f). Triple hybridization $(\mathbf{g}, \mathbf{h})$ using a digoxigenin labeled 5S rDNA probe (red), a biotin labeled histone $\mathrm{H} 3$ gene probe (red) and a double (biotin and digoxigenin) labeled 285 rDNA probe (yellow, as a result of the mixture of green and red) reveals that the histone gene clusters are independent of the major rDNA clusters in B. puniceus $(\mathbf{g}, \mathbf{i})$ and in B. rodriguezi $(\mathbf{h}, \mathbf{j})$. In both species, one of the chromosome pairs bearing a 55 rDNA signal also carries one of the core histone gene signals $(\mathbf{g}, \mathbf{h}, \mathbf{i}, \mathbf{j})$. The metaphase plate in $\mathbf{g}$, $\mathbf{i}$ was also re-hybridized using a PNA telomeric probe (fluorescein, green). Scale bars, $5 \mu \mathrm{m}$. 
Table 2 Relative lengths and centromeric indices of Brachidontes puniceus chromosomes

\begin{tabular}{cccccc}
\hline Pair & \multicolumn{2}{c}{ Relative length } & \multicolumn{2}{c}{ Centromeric index } & \multirow{2}{*}{ Type } \\
\cline { 2 - 4 } & Mean & SE & Mean & SE & \\
\hline 1 & 8.72 & 0.53 & 43.48 & 0.78 & $\mathrm{~m}$ \\
2 & 7.99 & 0.50 & 25.48 & 1.09 & $\mathrm{sm} / \mathrm{st}$ \\
3 & 7.20 & 0.27 & 16.21 & 0.90 & $\mathrm{st}$ \\
4 & 7.05 & 0.34 & 20.56 & 0.77 & $\mathrm{st}$ \\
5 & 6.96 & 0.54 & 8.59 & 0.55 & $\mathrm{t}$ \\
6 & 6.56 & 0.40 & 24.66 & 1.20 & $\mathrm{sm} / \mathrm{st}$ \\
7 & 6.46 & 0.51 & 7.11 & 0.45 & $\mathrm{t}$ \\
8 & 6.16 & 0.46 & 7.96 & 0.78 & $\mathrm{t}$ \\
9 & 6.11 & 0.24 & 24.38 & 0.87 & $\mathrm{sm} / \mathrm{st}$ \\
10 & 5.84 & 0.28 & 27.94 & 0.84 & $\mathrm{sm}$ \\
11 & 5.83 & 0.43 & 8.10 & 0.64 & $\mathrm{t}$ \\
12 & 5.52 & 0.29 & 24.75 & 0.82 & $\mathrm{sm} / \mathrm{st}$ \\
13 & 5.26 & 0.27 & 29.39 & 1.01 & $\mathrm{sm}$ \\
14 & 5.13 & 0.23 & 21.76 & 0.91 & $\mathrm{St}$ \\
15 & 4.74 & 0.31 & 22.02 & 0.61 & $\mathrm{St}$ \\
16 & 4.49 & 0.33 & 30.43 & 0.76 & $\mathrm{Sm}$ \\
\hline
\end{tabular}

$\mathrm{m}$ : metacentric, sm: submetacentric, st: subtelocentric; t: telocentric; sm/st: submeta/subtelocentric

short arms of the telo/subtelocentric chromosome pairs \# 4 and \# 6 (Figure $1 \mathrm{i}, \mathrm{j}, \mathrm{k}$ ), but the one showing only three DAPI-/CMA+ regions (Figure $1 \mathrm{~m}, \mathrm{n}$ ) also presents only three major rDNA signals (Figure 10). The consistently bigger telomeric signals appear at the DAPI-/ CMA+ NORs.

FISH signals corresponding to the minor ribosomal genes were studied in 111 metaphases in B. puniceus and 150 in B. rodriguezi. As shown in Figure 2a, 5S rDNA signals are interstitially located on the long arms of chromosome pairs \# 4 and \# 6 in B. puniceus. In B. rodriguezi $5 \mathrm{~S}$ rDNA signals are also intercalary located on the long arms of two chromosome pairs, \# 3 and \# 4 (Figure 2b). The number of minor rDNA signals was always 4 in B. puniceus but 2 or 4 in different metaphase plates in B. rodriguezi. Double-color FISH experiments (Figure 2c, d) confirmed the presence of major and minor rDNA clusters on chromosome pair \# 4 in $B$. rodriguezi and therefore allowed the study of the distribution of the variable number of $5 \mathrm{~S}$ rDNA signals (Table 3). A $66.67 \%$ of the metaphase plates showed signals only on the NOR-bearing chromosome pair \# 4 . The remaining metaphases showed 4 signals on pairs \# 3 and \# 4 (32\%), being always weaker those in chromosome \# 3 (Figure $2 b, d, h, j$ ), or only 2 signals on pair \# 3 (1.33\%).

Core histone genes were mapped by FISH using both histone $\mathrm{H} 3$ and histone $\mathrm{H} 2 \mathrm{~B} / \mathrm{H} 2 \mathrm{~A}$ probes. FISH signals were analyzed in at least 20 complete metaphases per mussel in 5 individuals in each species. Core histone
Table 3 Number and proportion of metaphases showing 2 or 4 5S rDNA signals on chromosome pairs \# 3, not bearing 285 rDNA signals, and \# 4, also bearing 285 rDNA signals, on five specimens of Brachidontes rodriguezi

\begin{tabular}{cccccccc}
\hline Mussel & \multicolumn{2}{c}{ 2 signals, \# } & \multicolumn{2}{c}{ 2 signals, \# 4 } & \multicolumn{2}{c}{ 4 signals, \# 3, \# 4 } & Total \\
\cline { 2 - 6 } & $\mathbf{n}$ & $\mathbf{\%}$ & $\mathbf{n}$ & $\mathbf{\%}$ & $\mathbf{n}$ & $\mathbf{\%}$ & \\
\hline 1 & 0 & 0.00 & 15 & 60.00 & 10 & 40.00 & 25 \\
2 & 1 & 2.33 & 29 & 67.44 & 13 & 30.23 & 43 \\
3 & 1 & 4.17 & 8 & 33.33 & 15 & 62.50 & 24 \\
4 & 0 & 0.00 & 24 & 82.76 & 5 & 17.24 & 29 \\
5 & 0 & 0.00 & 24 & 82.76 & 5 & 17.24 & 29 \\
\hline Total & 2 & 1.33 & 100 & 66.67 & 48 & 32.00 & 150 \\
\hline
\end{tabular}

gene signals are interstitial to the long arms of chromosome pairs \# 6 and \# 10 in B. puniceus (Figure 2e). The signal in pair \# 10 is closer to the centromere. B. rodriguezi also shows intercalary signals on two chromosome pairs, \# 3 and \# 9 (Figure 2f). In this species the signal on chromosome pair \# 9 is closer to the centromere. Double-color FISH experiments using $\mathrm{H} 3$ and $\mathrm{H} 2 \mathrm{~B}$ / $\mathrm{H} 2 \mathrm{~A}$ histone gene probes labeled differently always showed coincident signals (not shown). In order to confirm the location of the histone gene clusters in relation to the minor and major rDNA clusters, double and triple-color FISH experiments were performed. One of the core histone gene clusters and one of the $5 \mathrm{~S}$ rDNA clusters are on the same chromosome pair (Figure $2 \mathrm{~g}, \mathrm{~h}$ ) both in B. puniceus (pair \# 6) and B. rodriguezi (\#3). The relative positions of the major rDNA, $5 \mathrm{~S} \mathrm{rDNA}$ and histone gene clusters are indicated on the karyotypes that appear on Figure 2i, j.

\section{Discussion}

The chromosomal characterization of the mussels of the family Mytilidae includes the knowledge of mitotic chromosome numbers and karyotypes in 32 species. Six of these species show the same diploid chromosome number $(2 \mathrm{n}=32)$ present in both Brachidontes puniceus and $B$. rodriguezi [8]. On the contrary, the only other species of this genus in which the karyotype has been described, B. pharaonis, shows $2 \mathrm{n}=28$ chromosomes [10]. The variability of chromosome numbers between species of the same genus is widespread in the family Mytilidae; with the exception of Mytilus, all genera of mussels in which karyotypes have been determined for more than one species show differences in chromosome numbers [34]. On the other hand, the coincidence in chromosome numbers in $B$. puniceus and $B$. rodriguezi is accompanied by considerable differences in karyotype composition.

The detection of the vertebrate telomeric (TTAGGG) repeat at chromosome ends in Brachidontes puniceus 
and $B$. rodriguezi agrees with results obtained in chromosomes of other species of bivalves [2], including the mussels Mytilus galloprovincialis [6,28] and Perumytilus purpuratus [5]. On the contrary, the interstitial telomeric sequences clearly detected by FISH in $P$. purpuratus [5] and presumably appearing in M. galloprovincialis [28] were not detected in these two species of Brachidontes. Although in bivalves telomeric sequences have only been isolated and characterized in Donax trunculus [28], the hybridization results obtained so far indicate that the bivalve telomeres are composed of tandem repeats of the hexanucleotide which also constitutes the vertebrate telomeric sequence.

The presence of major rDNA signals on CMA bright regions terminally located on a single chromosome pair in Brachidontes puniceus and on two chromosome pairs in $B$. rodriguezi is concordant with results obtained in other bivalves. NORs have been located in around 50 species of bivalves $[2,5]$ and are located at terminal positions on one to three chromosome pairs. In the family Mytilidae, the position of major rRNA genes is known in seven species. One NOR-bearing chromosome pair has been detected in B. pharaonis [10], two in Mytilus galloprovincialis [6], M. edulis [11], B. rodriguezi [8] and Perumytilus purpuratus [5], and three in M. trossulus and M. californianus [9]. The species of the genus Brachidontes show differences both in number and chromosomal location of the NORs. The single major ribosomal gene cluster appears at a terminal position on the long arm of one small subtelocentric chromosome pair in both B. puniceus and B. pharaonis [10]. However, the two major ribosomal gene clusters of $B$. rodriguezi are spread over the whole short arms of the two subtelocentric/telocentric chromosomes pairs [8].

The occurrence of individuals showing a different number of rDNA clusters to those usually found in the species has been described in many taxa, including humans [35]. In this sense, the presence of an additional NOR in one of the $B$. puniceus specimens is not remarkable and could be the result of a translocation process as proposed for human ectopic NORs [35]. The absence of one of the major rDNA clusters in one chromosome in $B$. rodriguezi can be attributed to unequal crossover events [36].

The mostly coincident FISH signal sizes obtained at the terminal NORs after using 28S rDNA and telomeric probes in both B. rodriguezi and B. puniceus might indicate that some telomeric repeats are interspersed within the major rDNA repeats; fiber-FISH and molecular analysis are necessary to confirm or discard this hypothesis. Although not common, interspersion of telomeric and major ribosomal DNA sequences has been observed in bivalves, such as the mussel Mytilus galloprovincialis [6] and the scallop Patinopecten yessoensis [20], and in other organisms such as fishes [37] and mammals [38]. The meaning of such organization is not well understood but a functional role in nucleolus organization for tandem repeats has been proposed [39].

The chromosomal location of $5 \mathrm{~S}$ rDNA clusters is only known in 15 species of bivalves [2,5]. In most of these species, minor rDNAs usually appear at interstitial loci [18-20]. The presence of two 5S rDNA clusters in both Brachidontes puniceus and B. rodriguezi differs from the results obtained in Mytilus edulis and M. galloprovincialis [11], in which four 5S rDNA clusters appear on three chromosome pairs, and Perumytilus purpuratus [5], showing three 5S rDNA clusters on two chromosome pairs. Regarding the other species of bivalves in which the location of these sequences is known, the Ostreidae $[13,14]$ and two species of Pectinidae [15,17] also show two $5 \mathrm{~S}$ rDNA clusters. On the contrary, Cerastoderma edule (Cardiidae) presents five clusters of $5 \mathrm{~S}$ rDNA on five different chromosome pairs [12] and most species of Pectinidae show a single 5S rDNA cluster $[16,18,20]$.

The variation in number of $5 \mathrm{~S}$ rDNA FISH signals detected in Brachidontes rodriguezi is mostly due to the presence or absence of signals in chromosome pair \# 3 . The small size of these signals probably indicates that the number of $5 \mathrm{~S}$ rDNA repeats at this locus is close to the minimum necessary for the signal to be detected. Similar variations in the number of $5 \mathrm{~S}$ rDNA signals have been detected in two other species of Mytilidae, Mytilus galloprovincialis and M. edulis [11].

Our results demonstrate that major and minor rDNA clusters are on different chromosome pairs in Brachidontes puniceus but that in $B$. rodriguezi one of the NOR-bearing chromosome pairs also carries one of the 5S rDNA clusters. This is also the case in Perumytilus purpuratus [5] and Chlamys farreri [16] but differs from the presence of both major and 5S rDNA clusters on different chromosome pairs in the rest of the bivalve species studied so far.

Histone genes are usually organized as tandem repeats in invertebrate genomes [40]. These clusters can be composed by a copy of each one of the core histone genes or both core and linker histone genes. Histone gene arrangement in bivalves has been studied in the mussels Mytilus edulis [21,23] and M. galloprovincialis $[22,24]$, and the scallop Chlamys farreri [25]. All of them present clusters of core histone genes ordered in the same way thus probably indicating a conserved arrangement. Our results showing hybridization signals at the same positions after FISH using $\mathrm{H} 3$ gene and $\mathrm{H} 2 \mathrm{~B} / \mathrm{H} 2 \mathrm{~A}$ gene probes point also to this situation in Brachidontes puniceus and B. rodriguezi. Histone genes are known to be located in two chromosome pairs in the mussel M. galloprovincialis [24] and the scallop 
Patinopecten yessoensis [27] but forming a single cluster in other mussel species, Perumytilus purpuratus [5], and in the scallops Argopecten irradians, Chlamys farreri and C. nobilis [27]. Therefore, in the family Mytilidae, the presence of two histone gene clusters in these two Brachidontes species coincides with the situation in $M$. galloprovincialis [24] but differs from the one in P. purpuratus [5].

One of the histone gene clusters and one of the $5 \mathrm{~S}$ rDNA clusters appear on the long arm of the same chromosome pair in both Brachidontes puniceus and B. rodriguezi. In addition, the relative positions of these clusters with respect to the centromere are similar in both species being the histone genes distal to the 5S rDNA. Although these facts seem to indicate that this chromosome is conserved, further analyses are necessary in order to determine their homology. The only other species of bivalves in which the position of these two sequences was investigated together is Perumytilus purpuratus [5]. In contrast with $B$. puniceus and B. rodriguezi, in $P$. purpuratus the single histone gene cluster and the $5 \mathrm{~S}$ rDNA clusters are located in different chromosome pairs.

The similarities in the chromosomal distribution of major rDNA, 5S rDNA and core histone gene clusters found in Brachidontes puniceus, B. rodriguezi and Perumytilus purpuratus [5] are not shared by Mytilus galloprovincialis $[11,22,24]$ and confirm the closeness of $P$. purpuratus to the species of Brachidontes, therefore keeping open the possibility of its assignation to this genus but discarding that $P$. purpuratus, $B$. rodriguezi and $B$. darwinianus belongs to the same taxon [41].

\section{Conclusions}

The FISH results obtained in this work after using major rDNA, 5S rDNA and histone gene probes allow unequivocally identifying four of the 16 chromosome pairs that compose the karyotypes of Brachidontes puniceus and B. rodriguezi. Additional research is in progress in order to find more markers that allow chromosome identification in Mytilidae and therefore to gain insights on chromosome evolution in this family.

\section{Acknowledgements \\ We wish to thank Pilar Alvariño, Nieves Santamaría and Angel Torreiro for their technical assistance and Sara Rocha, Emilio Rolán-Mosquera and Ines Trucco for kindly providing the mussels. We also thank Dr R Fallon for his help on copyediting the manuscript. This work was funded in part by grants from Ministerio de Ciencia y Tecnología (AGL2002-00681), Xunta de Galicia (PGIDIT03PXIC30102PN, Grupos de Referencia Competitiva: 2010/80) and Universidade de Vigo (64102C124).}

\section{Authors' contributions}

CPG undertook most of the cytogenetic procedures and collaborated on the molecular work, the bibliographic review, and the writing of this paper. JGV participated in the first steps of the amplification, cloning, characterization and mapping of the 55 rDNA.
PM participated in developing the molecular techniques and helped in the writing. JJP coordinated the study, helped in developing the laboratory techniques and cytogenetic analyses and coordinated the writing of the manuscript. All authors read and approved the final manuscript.

Received: 7 October 2010 Accepted: 10 December 2010

Published: 10 December 2010

\section{References}

1. Giribet G, Distel D: Bivalve phylogeny and molecular data. In Systematics and Phylogeography of Mollusks. Edited by: Lydeard C, Lindberg DR. Washington DC, Smithsonian Books; 2003:45-90.

2. Leitão $A$, Chaves R: Banding for chromosomal identification in bivalves: $A$ 20-year history. In Aquaculture 1. Dynamic Biochemistry, Process Biotechnology and Molecular Biology. Volume 2. Edited by: Russo R. Global Science Books; 2008:(Special Issue 1):44-49.

3. Thiriot-Quiévreux C: Review of the literature on bivalve cytogenetics in the last ten years. Cah Biol Mar 2002, 43:17-26.

4. Guo X, Wang Y, Xu Z: Genomic analyses using fluorescence in situ hybridization. In Aquaculture genome technologies. Edited by: Liu Z. Oxford, Blackwell Publishing; 2007:289-311.

5. Pérez-García C, Cambeiro JM, Morán P, Pasantes JJ: Chromosomal mapping of rDNAs, core histone genes and telomeric sequences in Perumytilus purpuratus (Bivalvia: Mytilidae). J Exp Mar Biol Ecol 2010, 395:199-205.

6. Martínez-Expósito MJ, Méndez J, Pasantes JJ: Analysis of NORs and NORassociated heterochomatin in the mussel Mytillus galloprovincialis Lmk. Chromosome Res 1997, 5:268-273.

7. Insua A, Méndez J: Physical mapping and activity of ribosomal RNA genes in mussel Mytilus galloprovincialis. Hereditas 1998, 128:189-194.

8. Torreiro A, Martínez-Expósito MJ, Trucco Ml, Pasantes JJ: Cytogenetics in Brachidontes rodriguezi d'Orb (Bivalvia, Mytilidae). Chromosome Res 1999, 7:49-55.

9. González-Tizón AM, Martínez-Lage A, Rego I, Ausio J, Méndez J: DNA content, karyotypes, and chromosomal location of 18S-5.8S-28S ribosomal loci in some species of bivalve molluscs from the Pacific Canadian coast. Genome 2000, 43:1065-1072.

10. Vitturi R, Gianguzza $P$, Colomba MS, Riggio S: Cytogenetic characterization of Brachidontes pharaonis (Fisher P, 1870): Karyotype, banding and fluorescent in situ hybridization (FISH) (Mollusca: Bivalvia: Mytilidae). Ophelia 2000, 52:213-220.

11. Insua A, Freire R, Ríos R, Méndez J: The 5S rDNA of mussels Mytilus galloprovincialis and $M$. edulis: sequence, variation and chromosomal location. Chromosome Res 2001, 9:495-505.

12. Insua A, Freire $\mathrm{R}$, Méndez J: The $5 \mathrm{~S}$ rDNA of the bivalve Cerastoderma edule: nucleotide sequence of the repeat unit and chromosomal location relative to 18-28S rDNA. Genet Sel Evol 1999, 31:509-518.

13. Cross I, Díaz E, Sánchez I, Rebordinos L: Molecular and cytogenetic characterization of Crassostrea angulata chromosomes. Aquaculture 2005, 247:135-144.

14. Wang Y, Xu Z, Guo X: Chromosomal mapping of 5 S ribosomal RNA genes in the eastern oyster, Crassostrea virginica Gmelin by fluorescence in situ hybridization. J Shellfish Res 2005, 24:959-964.

15. Insua A, López-Piñón MJ, Méndez J: Characterization of Aequipecten opercularis (Bivalvia: Pectinidae) chromosomes by different staining techniques and fluorescent in situ hybridization. Genes Genet Syst 1998, 73:193-200.

16. Wang $Y$, Guo $X$ : Chromosomal rearrangement in Pectinidae revealed by rRNA loci and implications for bivalve evolution. Biol Bull 2004, 207:247-256.

17. López-Piñón MJ, Insua A, Méndez J: Chromosome analysis and mapping of ribosomal genes by one and two-color fluorescent in situ hybridization in Hinnites distortus (Bivalvia: Pectinidae). J Heredity 2005, 96:52-58.

18. Insua A, López-Piñón MJ, Freire R, Méndez J: Karyotype and chromosomal location of $18 \mathrm{~S}-28 \mathrm{~S}$ and $5 \mathrm{~S}$ ribosomal DNA in the scallops Pecten maximus and Mimachlamys varia (Bivalvia: Pectinidae). Genetica 2006, 126:291-301.

19. Huang $X, \mathrm{Hu}$ J, Hu X, Zhang G, Zhang L, Wang S, Lu W, Bao Z: Cytogenetic characterization of the bay scallop, Argopecten irradians irradians, by multiple staining techniques and fluorescence in situ hybridization. Genes Genet Syst 2007, 82:257-263. 
20. Huang $X, H u X, H u$ J, Zhang L, Wang S, Lu W, Bao Z: Mapping of ribosomal DNA and (TTAGGG)n telomeric sequence by FISH in the bivalve Patinopecten yessoensis (Jay, 1857). J Moll Stud 2007, 73:393-398.

21. Drabent B, Kim JS, Albig W, Prats E, Cornudella L, Doenecke D: Mytilus edulis histone gene clusters containing only H1 genes. J Mol Evol 1999, 49:645-655.

22. Eirín-López JM, González-Tizón AM, Martínez A, Méndez J: Molecular and evolutionary analysis of mussel histone genes (Mytilus spp): possible evidence of an "orphon origin" for $\mathrm{H} 1$ histone genes. J Mol Evol 2002, 55:272-283.

23. Albig W, Warthorst U, Drabent B, Prats E, Cornudella L, Doenecke D: Mytilus edulis core histone genes are organized in two clusters devoid of linker histone genes. J Mol Evol 2003, 56:597-606.

24. Eirín-López JM, Ruiz MF, González-Tizón AM, Martínez A, Sánchez L, Méndez J: Molecular evolutionary characterization of the mussel Mytilus histone multigene family: first record of a tandemly repeated unit of a five histone genes containing an $\mathrm{H} 1$ subtype whit "orphon" features. J Mol Evol 2004, 58:131-144.

25. Li C, Song L, Zhao J, Zou H, Su J, Zhang H: Genomic organization, nucleotide sequence analysis of the core histone genes cluster in Chlamys farreri and molecular evolution assessment of the $\mathrm{H} 2 \mathrm{~A}$ and H2B. DNA Seq 2006, 17:440-445.

26. González-Romero R, Ausió J, Méndez J, Eirín-López JM: Early evolution of histone genes: Prevalence of an 'orphon' $\mathrm{H} 1$ lineage in Protostomes and birth-and-death process in the H2A family. J Mol Evol 2008, 66:505-518.

27. Zhang $L$, Bao Z, Wang $S$, Huang $X$, Hu J: Chromosome rearrangements in Pectinidae (Bivalvia: Pteriomorphia) implied based on chromosomal localization of histone H3 gene in four scallops. Genetica 2007, 130:193-198.

28. Plohl M, Prats E, Martínez-Lage E, González-Tizón A, Méndez J, Cornudella L: Telomeric localization of the vertebrate-type hexamer repeat, (TTAGGG) $\mathrm{n}$, in the wedgeshell clam Donax trunculus and other marine invertebrate genomes. J Biol Chem 2002, 277:19839-19846.

29. Levan A, Fredga K, Sandberg AA: Nomenclature for centromeric position on chromosomes. Hereditas 1964, 52:201-220.

30. Estoup A, Largiadèr CR, Perrot E, Chourrout D: Rapid one-tube DNA extraction for reliable PCR detection of fish polymorphic markers and transgenes. Mol Mar Biol Biotechnol 1996, 5:295-298.

31. White TJ, Burms T, Lee S, Taylor JW: Amplification and direct sequences of fungal ribosomal RNA genes for phylogenetics. In PCR protocols: a guide to methods and applications. Edited by: Inmus MA, Guelfand DH, Sminsky JJ, White TJ. New York, Academic Press; 1990:315-322.

32. Fang BL, De Baere R, Vandenberghe A, De Wachter R: Sequences of three molluscan $5 \mathrm{~S}$ ribosomal RNAs confirm the validity of a dynamic secondary structure model. Nucleic Acids Res 1982, 10:4679-4685.

33. Hurtado NS, Pasantes JJ: Surface spreading of synaptonemal complexes in the clam Dosinia exoleta (Mollusca, Bivalvia). Chromosome Res 2005, 13:575-580.

34. Thiriot-Quiévreux C: Advances in cytogenetics of aquatic organisms. In Genetics and Evolution of Aquatic Organisms. Edited by: Beaumont AR. London, Chapman 1994:369-388.

35. Kühl $H$, Rötger $S$, Heilbronner $H$, Enders $H$, Schempp W: Loss of $Y$ chromosomal PAR2-region in four familial cases of satellite $Y$ chromosomes (Yqs). Chromosome Res 2001, 9:215-222.

36. Deiana AM, Cau A, Salvadori S, Coluccia E, Cannas R, Milia A, Tagliavini J: Major and $5 \mathrm{~S}$ ribosomal sequences of the largemouth bass Micropterus salmoides (Perciformes, Centrarchidae) are localized in GC-rich regions of the genome. Chromosome Res 2000, 8:213-218.

37. Abuín M, Martínez P, Sánchez L: Localization of repetitive telomeric sequence (TTAGGG)n in four salmonid species. Genome 1996, 39:1035-1038.

38. Zhdanova NS, Minina JM, Karamisheva TV, Draskovic I, Rubtsov NB, Londoño-Vallejo JA: The very long telomeres in Sorex granarius (Soricidae, Eulipothyphla) contain ribosomal DNA. Chromosome Res 2007, 15:881-890.

39. Kaplan FS, Murray J, Sylvester JE, Gonzalez IL, O'Connor P, Doering JL, Muenke M, Emanuel BS, Zasloff MA: The topographic organization of repetitive DNA in the human nucleolus. Genomics 1993, 15:123-132.

40. Eirín-López JM, González-Romero R, Dryhurst D, Méndez J, Ausió J: Longterm evolution of histone families: old notions and new insights into their mechanisms of diversification across eukaryotes. In Evolutionary Biology. Edited by: Pontarotti P. Berlin, Springer-Verlag; 2009:139-162.

41. Aguirre ML, Pérez SI, Sirch YN: Morphological variability of Brachidontes Swainson (Bivalvia, Mytilidae) in the marine Quaternary of Argentina (SW Atlantic). Paleogeogr Paleoclimatol Paleoecol 2006, 239:100-125.

doi:10.1186/1471-2156-11-109

Cite this article as: Pérez-García et al.: Chromosomal mapping of rRNA genes, core histone genes and telomeric sequences in Brachidontes puniceus and Brachidontes rodriguezi (Bivalvia, Mytilidae). BMC Genetics 2010 11:109.

\section{Submit your next manuscript to BioMed Central and take full advantage of:}

- Convenient online submission

- Thorough peer review

- No space constraints or color figure charges

- Immediate publication on acceptance

- Inclusion in PubMed, CAS, Scopus and Google Scholar

- Research which is freely available for redistribution

Submit your manuscript at www.biomedcentral.com/submit
C) Biomed Central 